\title{
Optimization of Multilevel Ethanol Leaching Process of Porang Flour (Amorphophallus muelleri) Using Response Surface Methodology
}

\author{
Anni Faridah ${ }^{1}$, Simon Bambang Widjanarko ${ }^{2}$ \\ ${ }^{1}{ }^{1}$ Faculty of Technology, Padang State University, Padang, Jalan Prof. \\ Dr. Hamka Air TawarPadang - Sumatera Barat, Indonesia \\ E-mail: faridah.anni@gmail.com \\ ${ }^{2}$ Faculty of Agricultural Technology, Brawijaya University, Malang,Jalan Veteran, Malang,JawaTimur, Indonesia \\ E-mail: simonbw@brawijaya.ac.id
}

\begin{abstract}
Porang flour is a processed product derived from porang tuber (Amorphophallus oncophyllus), contains polysaccharide hydrocolloid such as glucomannan and it can beused as gelatinization, viscosity, filming, emulsifier and stabilizer agent. Porang flour has low content of glucomannan, contributing to its dark brown color and contains high level of calcium oxalate which can cause itching, irritation and other health effects. In this study, the multilevel ethanol optimization and maceration method were used to extract the glucomannan content from porang flour by the leaching process. Response surface methodology (RSM), Central Composite Design $(C C D)$ on three independent variables leaching time $\left(X_{1}\right)$, stirring speed $\left(X_{2}\right)$ and ratio of solvent to flour $\left(X_{3}\right)$ with response of glucomannan content and calcium oxalate) were used as a tools to study the optimum responses. Responses model were quadratic with optimal condition as follows: leaching time was $4 \mathrm{~h} 6 \mathrm{~min}$ and $18 \mathrm{sec}$, stirring speed was at $443.45 \mathrm{rpm}$ and ratio of solvent to flour was $8.92 \mathrm{ml} / \mathrm{g}$. Under these conditions, the experimental yield of glucomannan content and calcium oxalate were 79.19 $\%$ and $0.08 \%$, respectively, which were very close to the predicted values of $79.26 \%$ and $0.07 \%$, respectively.
\end{abstract}

Keywords — Response Surface Methodology; Glucomannan; Calcium Oxalate; Optimization; Porang Flour.

\section{INTRODUCTION}

Porang flour is a processed product from porang tuber (Amorphophallusoncophyllus) produced. Using stamp mill andcontains about $67.5 \%$ (Faridah, 2011). This is much lower than the normal glucomannan level needed which is about $\geq 90 \%$. Thus, there is a need to conduct studies on how to enhance the recovery rates of glucomannan in porang tuber.

Glucomannan is a soluble dietary fiber that has strong hydrocolloid properties and calorie content. Due to its glucomannan content, porang flour have potential role as a major export commodity in food, non-food and healthpurposing manufactured-food (Kohyama et al., 1993). Glucomannan, due its high fiber contents, can be used as a food additive.

In Indonesia, the main problems on the development of porang flour were due to the fact that the after processed flour has low levels of glucomannan and high presence of calcium oxalate. It is a well known facts that calcium oxalate causes itching, skin irritation, crystallization in the kidney and other health's effects. Therefore, it has not been applied in the manufacturing of food product in Indonesia. So, it is clear that improving the glucomannan and reducing the calcium oxalate in porang flouris very important to enable it to be used in food manufacturing. In this study, recovery of glucomannan was conducted by the addition of porang flour to ethanol solution or leaching by multilevel ethanol using RSM.

Water and organic solvent as media, which have miscible properties, can be use in purifying the porang flour. Ethanol solvent has volatile properties, colorless, and non-toxic to human life (Sugiyama et al., 1971;Widjanarko et al., 2011). Ethanol will not propagate porang flour expansion. To date, there is a dearth of information on the method for the recovery of porang flour with high glucomannan content. The objectives of this research were to optimize the time, the stirring speed and the best ratio between multilevel ethanol to porang flour, in order to producelow level calcium oxalate and high level of glucomannan content.

\section{MATERIALS AND METHODS}

\section{A. Materials}

Porang or local name for conjac bulb, native to Indonesia, with diameter ranged $15-25 \mathrm{~cm}$, height ranged $5-10 \mathrm{~cm}$ and 
weight ranged 500-2500 $\mathrm{g}$ were obtained fromSumber Bendo Village, Saradan Subdistrict, Madiun Regency,Indonesia. The chemicals with pro analysis (p,a) purity were $\mathrm{NaOH}$, formic acid, concentrated $\mathrm{HCl}$ (37\%), concentrated $\mathrm{H}_{2} \mathrm{SO}_{4}(95 \%), \mathrm{CaCl}_{2}$, ether, metil red indicator, phenolphetaline (pp) indicator, $\mathrm{NH}_{4} \mathrm{OH}$, Kjeldahl tablet, boric acid $30 \%$, sodium sulfate, dinitrosalycilicacid (DNS).

\section{B. Extraction methods}

Porang flour (25 g) was weighed and transferred into sterile beaker glass. To extract the porang flour, $200 \mathrm{~mL}$ of ethanol $40 \%$ and $50 \mathrm{~mL}$ hydrogen peroxide $0.5 \%$ were added to the mixture and stirred using homogenizer based on the design described in Table 2. Porang flour was filtered, and the deposit was rinsed using ethanol $60 \%$ and was subjected to the mixture. The solution of porang flour was filtered from deposit and separated from filtrate. The deposit was rinsed using ethanol $80 \%$, and then filtered using Whatman paper 41 (length : $35 \mathrm{~mm}$,width : $5 \mathrm{~mm}$ ). The deposit was dehydrated by drying in oven at $40^{\circ} \mathrm{C}$ for $12 \mathrm{~h}$ to produce porang flour from maceration extraction.

\section{Analysis methods}

Water content was determined by weight difference after drying of samples,following the official method of AOAC (1995). Fat content was determined using aSoxhlet apparatus according to AOAC (1995). Protein content was calculatedfrom the nitrogen content $(\mathrm{N} \%: 6.25)$ analyzed by Kjeldahl method. Ash wasdetermined gravimetrically (AOAC,1995). Starch content as described by Zapata etal. (2004). Yield was calculated based on the weight of the crude porang flour to thetotal weight of porang used. Calcium oxalate was determined as described by Ukpabi and Ejidoh(1989) and glucomannan assay was conducted as described by Peying et al. (2002). Scanning electron microscope (SEM) (Instruction Manual FEI type InspectS50) was used to observe microscopically on rough porang flour and leaching optimization process of porang flour was carried out using maceration method.

\section{Experimental design}

The improving of glucomannan content and reducing of calcium oxalate content by multi level ethanol were optimized using RSM, employing the CCD. The range and center point values of three independent variables were as presented in Table 1 were based on the results of preliminary experiments on the extraction of porang flour as described under the extraction method section in this study (Widjanarko etal., 2011). Leaching time (X1), stirring speed (X2), and ratio of solvent ethanol toflour (X3) were chosen for independent variables

All treatmentscomprised of 20 proceses of leaching, in which each process condition followed thecentral composite design. Analysis of the experimental designand calculation of predicted data were carried out using Design expert Softwareversion 7.1 to estimate the responses. The behavior of the system was explained bythe following quadratic equation:
$Y=\beta_{0}+\sum_{i=1}^{3} \beta_{i} X_{i}+\sum_{i=1}^{3} \beta_{i i} X_{i}^{2}+\sum_{\mathrm{i}=1}^{2} \sum_{\mathrm{j}=2}^{3} \beta_{\mathrm{i}, \mathrm{j}} X_{i} X_{j}+\varepsilon$

where $\mathrm{Y}$ is the observation response, $\beta 0$ is the intercept, $\beta \mathrm{i}$ is linear coefficients, $\beta$ iiis quadratic coefficients, $\beta \mathrm{ij}$ is treatment interaction coefficients, $\mathrm{Xi}$ is treatment codefor " $\mathrm{i}$ " factor and $\mathrm{Xj}$ is treatment code for " $\mathrm{j}$ " factor.

TABLE I

INDEPENDENT VARIABLES AND THEIR LEVELS USED FOR CCD

\begin{tabular}{|l|l|l|l|l|l|}
\hline \multirow{2}{*}{$\begin{array}{l}\text { Independent } \\
\text { variables }\end{array}$} & \multicolumn{5}{|c|}{ Levels } \\
\cline { 2 - 6 } & $\mathbf{- 1 , 6 8}$ & $\mathbf{- 1}$ & $\mathbf{0}$ & $\mathbf{+ 1}$ & $\mathbf{+ 1 , 6 8}$ \\
\hline $\begin{array}{l}\text { Leachig time (h) } \\
\text { (X1) }\end{array}$ & 2,32 & 3 & 4 & 5 & 5,68 \\
$\begin{array}{l}\text { Stirring speed } \\
\text { (rpm) (X2) }\end{array}$ & $1: 4.64$ & 200 & 400 & 600 & 736,36 \\
$\begin{array}{l}\text { Ratio of solvent } \\
\text { toflour (X3) }\end{array}$ & & & $1: 8$ & $1: 10$ & $1: 11.36$ \\
\hline
\end{tabular}

TABLE II

CENTRAL COMPOSITE ARRANGEMENT FOR INDEPENDENT VARIABLES AND THEIRRESPONSE

\begin{tabular}{|c|c|c|c|c|c|}
\hline \multirow{2}{*}{ No } & \multicolumn{3}{|c|}{ Flour parameters } & \multicolumn{2}{c|}{ Response } \\
\cline { 2 - 6 } & $\begin{array}{c}\text { ing } \\
\text { time (h) }\end{array}$ & $\begin{array}{c}\text { Stirring } \\
\text { speed } \\
\text { (rpm) }\end{array}$ & $\begin{array}{c}\text { Ratio of } \\
\text { solvent to } \\
\text { flour (v/b) }\end{array}$ & $\begin{array}{c}\text { Glucomanan } \\
(\%)\end{array}$ & $\begin{array}{c}\text { Ca-Ox } \\
(\%)\end{array}$ \\
\hline 1 & 5 & 600 & $1: 10$ & 69,37 & 0,09 \\
\hline 2 & 4 & 400 & $1: 8$ & 79,08 & 0,07 \\
\hline 3 & 5,68 & 400 & $1: 8$ & 65,11 & 0,12 \\
\hline 4 & 3 & 200 & $1: 10$ & 76,92 & 0,14 \\
\hline 5 & 3 & 600 & $1: 6$ & 62,97 & 0,12 \\
\hline 6 & 4 & 400 & $1: 8$ & 79,11 & 0,07 \\
\hline 7 & 4 & 400 & $1: 8$ & 81,07 & 0,08 \\
\hline 8 & 5 & 200 & $1: 6$ & 65,04 & 0,1 \\
\hline 9 & 4 & 400 & $1: 4.64$ & 75,58 & 0,13 \\
\hline 10 & 5 & 600 & $1: 6$ & 70,14 & 0,1 \\
\hline 11 & 4 & 63,64 & $1: 8$ & 62,73 & 0,15 \\
\hline 12 & 4 & 400 & $1: 11.36$ & 79,43 & 0,11 \\
\hline 13 & 4 & 400 & $1: 8$ & 79,02 & 0,1 \\
\hline 14 & 2,32 & 400 & $1: 8$ & 62,14 & 0,17 \\
\hline 15 & 3 & 200 & $1: 6$ & 68,58 & 0,14 \\
\hline 16 & 5 & 200 & $1: 10$ & 67,98 & 0,1 \\
\hline 17 & 4 & 400 & $1: 8$ & 78,07 & 0,07 \\
\hline 18 & 4 & 400 & $1: 8$ & 76,21 & 0,07 \\
\hline 19 & 3 & 600 & $1: 10$ & 70,87 & 0,12 \\
\hline 20 & 4 & 736,36 & $1: 8$ & 65,73 & 0,08 \\
\hline
\end{tabular}

\section{E. Statistical analyses}

The responses obtained from each set of experimental design (Table 1) weresubjected to multiple non-linear 
regressions using the Design Expert software(Version7.1, Stat-Ease Inc., Minneapolis, MN). The quality of the fit of the polynomialmodel equation was expressed by the coefficient of determination, R2 and thesignificances of the regression coefficient were checked by F-test and p-value.

\section{RESULTS AND DISSCUSION}

\section{A. Fitting the model}

Response surface methodhology in this research was used to determine theappropriate model for predicting the responses of glucomannan and calcium oxalatecontent. Montgomery (2001) noted that model analysis are used to determineappropriate model in RSMmethodology, which are subsequentlyused to predict the response for independent variable. The evaluated modelincluded linear, 2FI (interaction), quadratic or cubic. The selection of model wasconducted based on: P-value model, lack of fit test, and model summary statistics $\left(\mathrm{R}^{2}\right.$, Adjusted $\mathrm{R}^{2}$ and std dev. (Table 3) (Bradley,2007; Bezerra et al., 2008).

TABLE III

ANALYSIS OF VARIANCE (ANOVA) FOR FITTED QUADRATIC POLYNOMIAL MODEL

\begin{tabular}{|c|c|c|c|c|c|}
\hline Source & $\begin{array}{c}\text { Sum of } \\
\text { squares }\end{array}$ & d.f & $\begin{array}{l}\text { Means } \\
\text { quare }\end{array}$ & $\begin{array}{c}\mathbf{F} \text { - } \\
\text { value }\end{array}$ & $\begin{array}{c}\text { p-value } \\
\text { Prob > F }\end{array}$ \\
\hline \multicolumn{6}{|c|}{ Glucomannan } \\
\hline Model & 776,83 & 9 & 86,3140 & 21,3394 & $<0,0001$ \\
\hline Linier & 45,59 & 3 & 15,20 & 0,32 & 0,8143 \\
\hline $2 \mathrm{FI}$ & 68,08 & 3 & 22,69 & 0,42 & 0,7422 \\
\hline Quadratic & 663,16 & 3 & 221,05 & 54,65 & $<0,0001$ \\
\hline Qubic & 23,58 & 4 & 5,89 & 2,10 & 0,1995 \\
\hline Residual & 40,4482 & 10 & 4,0448 & & \\
\hline $\begin{array}{c}\text { Lack of } \\
\quad \text { Fit }\end{array}$ & 27,8410 & 5 & 5,5682 & 2,2083 & 0,2025 \\
\hline Pure erron & 12,6072 & 5 & 2,5214 & & \\
\hline Cor total & 817,2746 & 19 & & & \\
\hline \multicolumn{6}{|c|}{$\mathrm{R}^{2}=0,9505$, Adjusted $R^{2}=0,9060, \quad$ std. dev. $=2,01$} \\
\hline \multicolumn{6}{|c|}{ Ca-Oxalate } \\
\hline Model & 41,7075 & 9 & 4,6342 & 52,4315 & $<0.0001$ \\
\hline Linier & $5,555 \mathrm{E}-003$ & 3 & $1,852 \mathrm{E}-003$ & 2,72 & 0,0791 \\
\hline $2 \mathrm{FI}$ & $1,375 \mathrm{E}-004$ & 3 & $4,583 \mathrm{E}-005$ & 0,055 & 0,9821 \\
\hline Quadratic & $8,422 \mathrm{E}-003$ & 3 & 2,807E-003 & 12,00 & 0,0012 \\
\hline Qubic & $7,945 \mathrm{E}-004$ & 4 & $1,986 \mathrm{E}-004$ & 0,77 & 0,5816 \\
\hline Residual & 0,00234 & 10 & 0,000234 & & \\
\hline $\begin{array}{c}\text { Lack of } \\
\text { Fit }\end{array}$ & 0,001607 & 5 & 0,000321 & $\begin{array}{c}2,19134 \\
444\end{array}$ & 0,2047 \\
\hline Pure errot & 0,000733 & 5 & 0,000147 & & \\
\hline Cor total & 0,016455 & 19 & & & \\
\hline \multicolumn{6}{|c|}{$\mathrm{R}^{2}=0,8578$, Adjusted $R^{2}=0,7298, \quad$ std. dev. $=1,36$} \\
\hline
\end{tabular}

The selection of the model based on sequential model sum of square showed thatthe significant and advised model was quadratic (Table 3). When the pvalue is lessthan 0.05 , it shows that this variable is significant. When the $p$ value is less than 0.001 ,it shows that the variable is highly significant and that means this variable had a greaterinfluence than other variables (Cai et al., 2007). The other model suggestedbased on sequential model sum of square was quadratic, $\mathrm{P}<0.0001$ atglucomannan and $\mathrm{P}<0.0012$ at calcium oxalate, indicating that the fitness of this modelwas highly significant. While based on lack of fit tests at glucomannan and calcium oxalate contentwereP $>0,2025$ and $P>0.1056$ respectively, which implied aninsignificant difference relative to the pure error and a good fitness of the model.Analysis of variance from quadratic response surface showed that quadratic modelhas a significant effect to response.

Quadratic model has a least standard deviation compared with other modelsuch as the determination coefficient $\left(\mathrm{R}^{2}=\right.$ 0,9505), Adj. $R^{2}$ of 0.9060 to improvethe glucomannan content and $\mathrm{R}^{2}=0,9505$, Adj. $\mathrm{R}^{2}=0.7298$ to reduce the calciumoxalate content. It means that variables of leaching time, stirring speed and ratio ofsolvent to flour were significantly difference to response variance of $90.6 \%$ and $72.98 \%$, whilst the rests were $9.4 \%$ and $27.02 \%$ influenced to other factors whichwas not variables considered inthis research. Widjanarko et al. (2011) noted that leaching timeand the level of leaching play role to improve the glucomannan contentand reduce the calcium oxalate.

A value $R^{2}$ greater than 0,75 indicates aptness of the model is significant.The optimization of the extract of steviosides from stevia rebaudiana leaves using RSM have a value $\mathrm{R}^{2}=0.98$, $\mathrm{P}$-value $=0.0074$ andlack of fit $(\mathrm{P}>0.05)$ showed that quadratic model was significant (Puri et al., 2012).Silvaet al. (2007) research optimization of extraction of phenolics fromInga edulis leaves using RSM have a value $\mathrm{R}^{2}=0.85$ fortotal phenolic, $\mathrm{R}^{2}=0.87$ for total flavonoid and 0.96 for total flavonoid with lack of fit $(\mathrm{P}>0.05)$ showed that this model is significant.

\section{B. Response surface andinfluence of variables onyield}

Quadratic equation can be used to predicted the responses from several levels. Quadraticequation obtained:

to improvethe glucomannan content is :

$\mathrm{Y}_{1}=-46.64+43.22 \mathrm{X}_{1}^{2}+0.06 \mathrm{X}_{2}^{2}+5.75 \mathrm{X}_{3}^{2}+0.01 \mathrm{X}_{1} \mathrm{X}_{2}-$ $0.88 \mathrm{X}_{1} \mathrm{X}_{3}-1.30 \times 10^{-3} \mathrm{X}_{2} \mathrm{X}_{3}-5.10 \mathrm{X}_{1}{ }^{2}-1.22 \times 10^{-4} \mathrm{X}_{2}^{2}-0.05$ $\mathrm{X}_{3}{ }^{2}$

to reduce the calcium oxalate is :

$\mathrm{Y}_{2}=0.74-0.18 \mathrm{X}_{1}-3.15 \times 10^{-4} \mathrm{X}_{2}-1.83 \times 10^{-3} \mathrm{X}_{3}+1.88 \mathrm{x}$ $10^{-5} \mathrm{X}_{1} \mathrm{X}_{2}-2.5 \times 10^{-5} \mathrm{X}_{1} \mathrm{X}_{3}-1.25 \times 10^{-7} \mathrm{X}_{2} \mathrm{X}_{3}+0.02 \mathrm{X}_{1}^{2}+2.55$ $\mathrm{X} 10^{-7} \mathrm{X}_{2}^{2}+4.78 \times 10^{-6} \mathrm{X}_{3}{ }^{2}$

This research has 3 factors of variables, therefore there were 3 responsesgraphic which describe the relationship between leaching time, stirring speed andratio of solvent to flour. The effect of leaching time, stirring speed and ratio of solventto flour which quadratic to response of improving the glucomannan and reducing thecalcium oxalate were shown in Figure 1. 


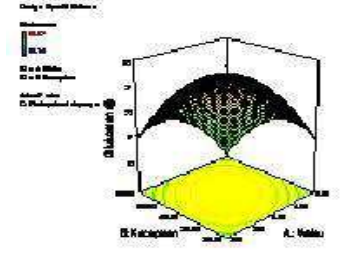

A
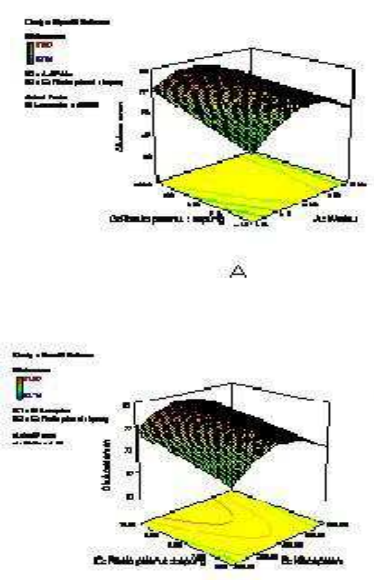

A
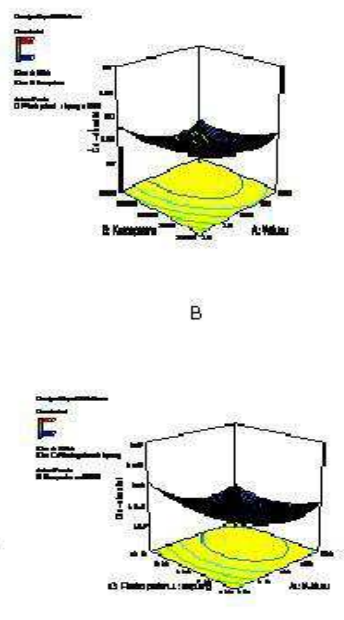

B

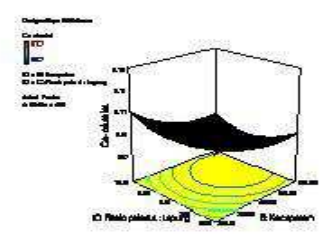

Fig. 1. The surface plots of the yield of glucomannan content (A) and calciumoxalate content (B) from porang flour as affected by leaching time, stirring speed andsolvent/flour ratio. Where (1) is leaching time and stirringspeed; (2) is leaching timeand solvent/flour ratio; (3) is stirring speed and solvent/flour ratio

1) Effect of leaching time to glucomannan content and calcium oxalate of porangflour: Leaching processed was carried out using 3 different ethanol concentrations (40\% ethanol for the first stage, $60 \%$ ethanolfor the second stage and $80 \%$ ethanolfor the third stage) and the difference in the concentrations of ethanol used may allow a distinctive component to dissolved based on the polarity. At higher concentration of ethanol used, the level of polarity will be decreasing, therefore allowing the non-polar components to be dissolved.

Shimizu and Shimara (2004) reported that $80 \%$ ethanol may cause distinctive component from porang flourto be dissolved and such ethanol concentration may reduce content of starch, protein, fat, oxalate, ash and calcium oxalate. While Ramadhan and Phaza (2007) also noted that porang flour leaching using ethanol could separatenonglucomannan compound as ethanol has a high polarity and is able to dissolved several compounds, such as resin, fat, oil, fatty acid, carbohydrate and others organic compound, preventing the glucomannan granule from expanding and dissolved into the solution.

Maceration method extraction time is appropriately required to ensure the distribution of extracted compounds from solid component to its solvent. Leaching time can play role in the leaching process, therefore the optimal leaching time can be achieved to produce flour which contains high glucomannan content, low calcium oxalate and has light porang flour colour.

Increasing leaching time that exceeds ofthe optimal leaching time can lead to decreasing glucomannan content and improving calcium oxalate content. However, its decreasing and increasing were not the same as the amount obtained using optimal leaching time. Kato (1970) reported that the degraded glucomannan will produce oligosaccharide suchas manosa, glucose, mannobiosa, manosil glucose, manotriosa, manobiosil glucose, manotetraosa, manotriosil glucose and manotetraosil glucose. Claver et al. (2010) also reported that leaching time can lead to the degradation of dissolved of glucomannan. The extractionof Chinese sorghum flour produces a low polysaccharide throughout the duration of the leaching time used. Caili et al. (2006) noted that the increase in the optimization of extraction time from xyloglucan produce less ofxyloglucan.

2) Effect of Stirring speed to glucomannan content and calcium oxalate ofporang flour: The faster stirring speed of leaching can stimulateloss of distinctive compound, therefore producing porang flour with high glucomannan content and low calcium oxalate. Glucomannan are located inside a cell which envelope the distinctive compound, such asstarch, protein and calcium oxalate. The leaching process using stirring can help toincrease ethanol abilityto dissolved compounds on the cell surface and also to release distinctive component out of the ethanol.

Keil (2007) noted that mechanical effect can increase the penetration from liquid tocell membrane wall, support the release of cell component, and increase the mass transfer. Stirring speed can also accelerate the extraction process or purification of glucomannan as reported by Povey (1988), who found that extraction has mechanical effect to enhance stronger liquid penetration energy into cell tissue and increase penetration of ethanol into the cell, therefore oxalate can be release easily.

Mason et al. (1996) and Paniwnyk et al. (2009) noted that mechanical effect increase the penetration of liquid into the wall of the cell membrane, supporting the release of cell components, and improve mass transfer. Caili et al. (2006) also suggested that the contribution of mechanical effect on the extraction of xyloglukan with physical phenomena, such as diffusion through cell walls and rinsing all broken cell content.

Sarkhosh (2012) noted that stirring or agitation on extraction process can increase the efficiency and shorten the time of extraction. Stirring process can enlarge the surface leaching area of extracted material with solvent to increase the efficiency and may lead to increase the temperature of extraction. The increase of extraction temperature may affect the extraction efficiency in several extraction processes. Metz and Ganor (2001) reported that the extraction efficiency increase at stirring speed of $800 \mathrm{rpm}$, and it will decrease at stirring speed of $1000 \mathrm{rpm}$. And Sarkosh (2012) also noted that the increasing of stirring speed may lead intensity pounded between particles in the materials is getting higher.

3) Effect of different ratio of solvent to flour to glucomannan content and calciumoxalate of porang flour: Glucomannan response increased and calcium oxalate decreased as the ratio of solvent increased. When ethanol 
solvent applied increase, the distinctivecomponent and nonglucomannan compounds also increase which can be dissolved by ethanol. The increasing of glucomannan and the decreasing of calcium oxalateon each leaching were directly proportional with the decreasing of distinction compounds such as non-glucomannan.

In general, a larger volume of solvent can dissolve constituents more effectively leading to improved extraction of routine and quercetin from Euonymus alatus (Thunb.) (Yang and Zhang, 2008). Gamse (2002) alsoreported that when the number of solvent used increase, the dissolve solid increasing due to the dispersion of the particle, as. higher solvent ratio will increase the mass transfer. Qing et al. (2009) noted that the penetration during mass transfer was affected by concentration gradient between solid and liquid. The higher solvent ratio will produce porang flour which contained high glucomannan.

Increase of solvent ratio above optimal response point can lead to decrease in the glucomannan content. Susanto (1999) reported that the comparison between number of sample and extracted liquid affected the efficiency of extraction. Yang and Zhang (2008) reported that an increasing in extraction of routine and quercetin with an increasing in the ratio of solvent : sample weight, especially when the ratio increased from 20 to $40 \mathrm{ml} / \mathrm{g}$ and will decrease after the ratio increased from 40 to $60 \mathrm{ml} / \mathrm{g}$. There were also similar findings reported by Claver et al. (2010), on the lower recovery polysaccharides extraction from Chinese sorghum powder when solvent ratio and time increased..

4) Response optimal point and verification: Stationary point value obtained from canonical analysis was carried out under optimal conditions: leaching time of $4 \mathrm{~h} 6 \mathrm{~min}$ and 18 sec, stirring speed $443.45 \mathrm{rpm}$ and ratio of solvent to flour $8.92 \mathrm{ml} / \mathrm{g}$ (Table 3). The response of glucomannan content and calcium oxalate content under optimal conditions were $79.19 \%$ and $0.075 \%$, respectively. These condition were optimal to obtained glucomannan and the lower of calcium oxalate on porang flour using maceration method.

Verification was performed by comparing response analysis value from theresearch to response value calculated by Design Expert.Accuracy level ofglucomannan and calcium oxalate were $99.91 \%$ and $97.33 \%$, respectively, whilst thedifference value were $0.09 \%$ and $2.66 \%$, respectively, obtained from realexperiments, demonstrating the validation of the RSM model (Table 4).

The difference of predicted valuewas significant $(\mathrm{p}>0.05)$ obtained from realexperiments which was demonstrated in the validation of the RSM model.The resultsof analysis confirmed that the responsemodel was adequate for reflecting theexpectedoptimization and the model was satisfactoryand accurate.

\section{5) Physicochemical analysis of optimal porang flour}

Leaching optimization process of maceration method may increase glucomannan and decrease calcium oxalate content of porang flour. As mentioned in Table 4, several trends were observed. An increase in glucomannan content was found in leaching optimization process of porang flour using maceration method from $67.02 \%$ to $79.19 \%$ and also a decrease in calcium oxalate was found from $0.28 \%$ to $0.07 \%$. This difference was further evidenced as seen in the microstructure using scanning electrom microscopy (SEM) at magnification $100 \mathrm{x}$ as shown in Figure 2.Microstructure of non-glucomannan from leaching at optimized process of porang flour using maceration method showed that granules surface of non-glucomannan decreased compared with rough porang flour due to impurities of glucomannan. This phenomenon showed that there were synchronization between data observed visually (Figure 2) and quantitatively (Table 5).

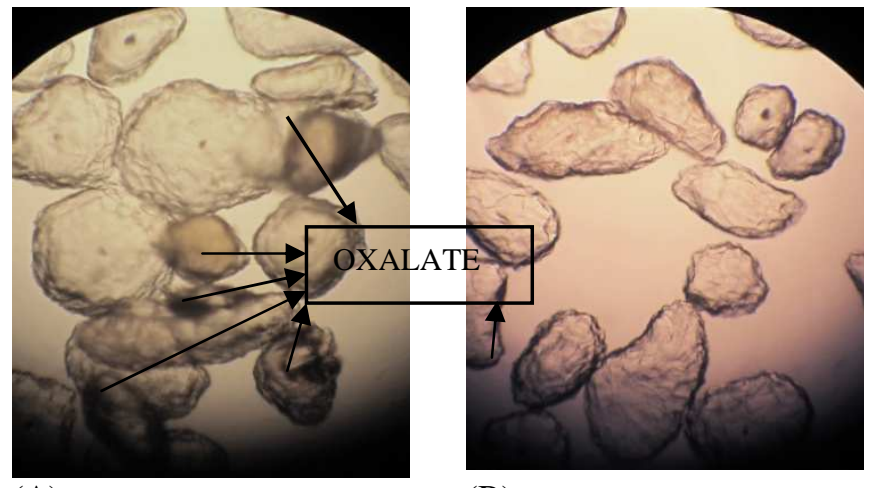

(A) (B)

Fig. 2.Microstructure of porang flour (A) before leaching, (B) leaching optimizationprocess using maceration method at magnification $100 \mathrm{x}$ 
TABLE IV

SELECTED OPTIMAL POINT FROM DESIGN EXPERT MODE

\begin{tabular}{|c|c|c|c|c|c|c|}
\hline & Leaching time (h) & Stirring speed (rpm) & Solvent/flour ratio & Glucomannan (\%) & Ca-oxalate (\%) & Desirability \\
\hline Prediction & 4.13 & 434.45 & $8.92: 1$ & 79.19 & 0,075 & 0,93 \\
\hline Actual & 4.13 & 434.45 & $8.92: 1$ & 79.26 & 0,073 & - \\
\hline \multicolumn{3}{|c|}{ Accuracy level (\%) } & 99.91 & 97.33 & 2.66 \\
\hline
\end{tabular}

TABLE 5

PHYSICOCHEMICAL PROPERTIES OF ROUGH PORANG FLOUR AND OPTIMIZATION OFMACERATION LEACHING OF PORANG FLOUR

\begin{tabular}{|l|c|c|}
\hline \multirow{2}{*}{ Parameter } & \multicolumn{2}{|c|}{ Rough porang flour } \\
\cline { 2 - 3 } & $\begin{array}{c}\text { Flour } \\
\text { optimization }(\%)\end{array}$ & $\begin{array}{c}\text { Optimization of } \\
\text { maceration leaching (\%) }\end{array}$ \\
\hline Moisture & 12.17 & 12.54 \\
\hline Ash content & 2.63 & 0.38 \\
\hline Starch content & 2.7 & 1.26 \\
\hline Protein content & 2.35 & 0.78 \\
\hline Fat content & 1.49 & 0.45 \\
\hline Oxalate content & 0.28 & 0.073 \\
\hline $\begin{array}{l}\text { Glucomannan } \\
\text { content }\end{array}$ & 67.019 & 79.187 \\
\hline White degree & $50.75^{*}$ & $53.19^{*}$ \\
\hline Viscosity & $6300^{* *}$ & $9633.33^{* *}$ \\
\hline Yield & 62.71 & 89.83 \\
\hline
\end{tabular}

Leaching at optimized conditions of porang flour using maceration method produced clear glucomannan granule and form of scales as shown in Figure 3. Takigami (2000) reported that the surface of glucomannan granule has a light colour, clean and more visible in the scales after leaching process.

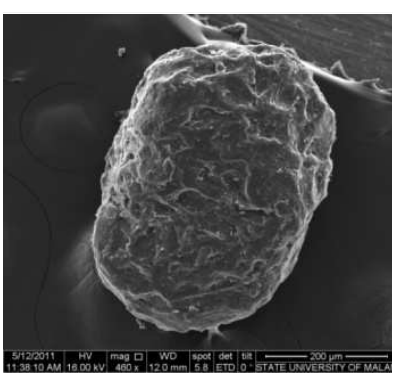

(A)

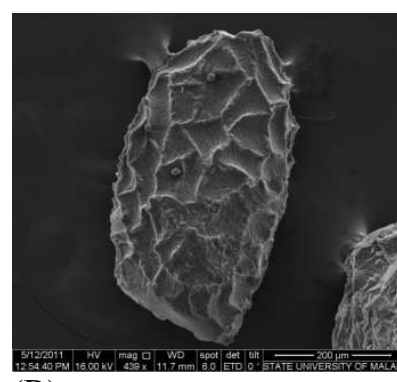

(B)
Fig. 3. Scanning electrom microscopy (SEM) observation on (A) rough porangflour; (B) Leaching optimization process of porang flour using maceration method

The other components of porang flour were decreased with the increased of glucomannan content such as starch, protein, fat and ash. A similar process was observed forcalcium oxalate due to its solubility properties to ethanol solution. Leaching time, stirring speed and ratio of optimal solvent played important role to increase solubility of starch, protein, fat and ash in several concentration of ethanol solvent. Shimize and Shimahara (2004) reported that ethanol solvent may lead to the decreasing amount of distinctive compounds such as starch, protein, fat, oxalate and ash compared with rough porang flour which produce high glucomannan content.

\section{CONCLUSION}

The response surface methodology was used to estimate and optimize theexperimental variables : leaching time (h), stirring speed (rpm) and ratio ofsolvent of flour $(\mathrm{ml} / \mathrm{g})$. All variables were the important factors which affectleaching process, on the response model values $(\mathrm{P}<0,0001)$ for glucomannancontent and calcium oxalate content. Response model was quadratic withoptimal condition as follows : leaching time of $4 \mathrm{~h} 6 \mathrm{~min}$ and $18 \mathrm{sec}$, stirring speed of $443.45 \mathrm{rpm}$ and ratio of solvent to flour $8.92 \mathrm{ml} / \mathrm{g}$ enhance the experimental yield of glucomannan content and calcium oxalate.

\section{REFERENCES}

[1] AOAC, Official methods of analysis, Washington DC, USA:Association of official analytical chemists, 1995.

[2] I.P. Claver, H. Zhang, Q. Li, Z. Kexue, and H. Zhou, "Optimization ofultrasonic extraction of polysaccharides fromchinese maltedsorghum using response surface methodology," Journal of Nutrition., vol. 9 (4), pp. 336-342, 2010.

[3] W. Cai, X. Gu, and J. Tang, "Extraction and preliminary structure discussionof soluble Opuntia Milpa Alta polysaccharide," Food Mach. vol. 23, pp. 68-71, 2007.

[4] Caili, T. Haijun, L. Quanhong, C. Tongyi, and D. Wenjuan, "Ultrasound-assisted extraction of xyloglucan from apple pomace", Ultrasonics Sonochemistry, vol.13, pp. $511-516,2006$.

[5] A.Faridah, S.B. Widjanarko, and A. Sutrisno, "Optimization study of increased content of glucomannan and diminution content of calcium oxalate in porang chip (Amorphophallus oncophyllus) during mechanical grinding process," in Proc. Indonesia Food Conference, 15-17 September Menado. Indonesia. 2011, paper 3, p. 12-17.

[6] T. Gamse, Liquid-liquid extraction and solid-liquid extraction. Institute of thermal process and enviromental engineering, Graz University of Technology, 2002.

[7] K. Kato, T. Watanabe, and K. Matsuda, "Studies on the chemical structureof konjac mannan. Part II. Isolation and characterization of oligosaccharides from the enzymic hydrolysis of the mannan," J.Agricultural and Biological Chemistry, vol.34, pp. 532-539, 1970.

[8] F.J. Keil, Modeling of process intensification, WILEY-VCH Verlag GmbH \& Co, KgaA, Weinheim, 2007.

[9] T.J. Mason, L. Paniwnyk, and J.P. Lorimer, "The use of ultrasound in foodtechnology", Ultrasonics Sonochemistry, vol.3, pp. S253-S260, 1996.

[10] V. Metz, and J. Ganor, "Stirring effect on kaolinite dissolution rate," Geochimica et Cosmochimica Acta, vol. 65 (20), pp.3475-3490, 2001.

[11] D.C. Montgomery, Design and Analysis of Experiment, $5^{\text {th }}$ ed., John Willey and Sons, Inc: New York, 2001.

[12] S. Ohashi, G.J. Shelso, A.L. Moirano, and W.L. Drinkwater, (2000). Clarified Konjac Glucomannan. US Patent. [Online] http://www.patentstorm.us.Retrieved:October 23, 2007.

[13] L. Paniwnyk, H. Cai, S. Albu, T.J. Mason, and R. Cole, "The enhancement and scale up of the extraction of anti-oxidants from 
Rosmarinus officinalis using ultrasound," Ultrasonics Sonochemistry, vol.16, pp. 287-292, 2009.

[14] L. Peiying, Z. Shenglin, Z. Guohua, C. Yan, O. Huaxue, H. Mei, W. Zhongfeng, X. Wei, and P. Hongyi, Professional Standart of The Peoeple'Republic of China for Konjac Flour. NY/T : 494-2002.

[15] M. Puri, D. Sharma, J.C. Barrow, and A.K. Tiwary, "Optimisation of novel method for the extraction of steviosides from Stevia rebaudiana leaves," Food Chem, vol.132, pp.1113-1120, 2012.

[16] An. Z. Qing, Q.Z. Zhi, F.Y. Xuen, H.F. Xue, L. Tao, and F.C. Shou, "Response surface optimization of ultrasound-assisted oil extraction from autoclaved almond powder," Food Chem. Vol.116 (2), pp.513 518, 2009.

[17] E. Ramadhan and A.H. Phaza, "The effect of ethanol, temperature and stage numberconcentration on ginger oleoresin extraction using batch," Thesis, Technic Faculty, Diponegoro University. Indonesia, 2007.

[18] M. Sarkhosh, A. Mehdinia, A. Jabbari, and Y. Yamini, "Determination of biphenyl and biphenyloxide in aqueous samples by head space single drop microextract ion coupled to gas chromatography," J.Braz. Chem. Soc. 00 (00): 1-8, 2012.

[19] M. Shimizu, and H. Shimahara (2004). Method Of selective separation of konjacfluor from the tubers of Amorphophallus konjac., [Online],

http://codex.foodnara.go.kr/lib/base_down.jsp?dr=eu\&fn=konjac\% $2 \mathrm{~g}$ um.pdf.

[20] E.M. Silva, H. Rogez, and Y. Larondelle, "Optimization of extraction of phenolics from Inga edulis leaves using response surface methodology," Separation and Purification Technology, vol.55, pp.381-387, 2007.

[21] S.B. Sudarmadji, Haryono, and Suhardi, Analayses procedure for food and agriculture product, $4^{\text {th }}$ ed. Liberti. Jogjakarta. Indonesia, 1997.

[22] N. Sugiyama, H. Shimahara, and T. Andoh, "Studies on mannan and related compounds. I. the purification of konjac mannan", Buletin ofthe Chemical Society of Japan, vol.45, pp.561-563, 1972.

[23] T. Susanto, Introduction of agricultural processing, Agriculture Faculty, Brawijaya University, Malang. Indonesia, 1999.

[24] U.J. Ukpabi, and J.I. Ejidoh, "Effect of deep oil frying on the oxalate contentand the degree of Itching of cocoyams (Xanthosoma and Colocasia spp). Technical Paper presented at the $5^{\text {th }}$ Annual Conference of The Agricultural Society of Nigeria, Federal University of Technology, Owerri, Nigeria, 3-6 Sept 1989.

[25] S.B. Widjanarko, A. Faridah, and A. Sutrisno, "Effect of multi level ethanol leaching on phisico-chemical properties of konjac flour (Amorphophallus oncophyllus). The 12th Asean food conference. 1618 June 2011, Bangkok, Thailand.

[26] J. Wu, R.E. Aluko, and H. Corke, "Partial least-squares regression study ofthe effects of wheat flour composition, protein and starch quality characteristics on oil content of steamed-and-fried instant noodles," Journal of Cereal Science, vol.44, pp.117-126, 2006.

[27] Y. Yang, and F. Zhang, "Ultrasound-assisted extraction of rutin and quercetin from Euonymus alatus (Thunb.) Sieb," Ultrasonic sonochemistry, vol.15, pp. 308-313, 2008.

[28] C. Zapata, E. Deleens, S. Chaillou, and C. Magne, "Partitioning andmobilization of starch and $\mathrm{N}$ reserve in grapevine (Vitis vinifera L.)," Journal of Plant Physiology, vol.161, pp. 1031-1040, 2004. 